NBER WORKING PAPER SERIES

\title{
IMMIGRANTS' COMPLEMENTARITIES AND NATIVE WAGES: EVIDENCE FROM CALIFORNIA
}

\author{
Giovanni Peri \\ Working Paper 12956 \\ http://www.nber.org/papers/w12956 \\ NATIONAL BUREAU OF ECONOMIC RESEARCH \\ 1050 Massachusetts Avenue \\ Cambridge, MA 02138 \\ March 2007
}

I am grateful to Hans Johnson, Jed Kolko, Ethan Lewis, David Neumark, Steven Raphael, Deborah Reed and participants to several seminars for helpful comments. Benjamin Mandel provided extremely competent assistance in editing the paper and very valuable comments. The views expressed herein are those of the author(s) and do not necessarily reflect the views of the National Bureau of Economic Research.

(C) 2007 by Giovanni Peri. All rights reserved. Short sections of text, not to exceed two paragraphs, may be quoted without explicit permission provided that full credit, including $\odot$ notice, is given to the source. 
Immigrants' Complementarities and Native Wages: Evidence from California

Giovanni Peri

NBER Working Paper No. 12956

March 2007

JEL No. F22,J31,J61,R23

\begin{abstract}
$\underline{\text { ABSTRACT }}$
As of 2004 California employed almost $30 \%$ of all foreign born workers in the U.S. and was the state with the largest percentage of immigrants in the labor force. It received a very large number of uneducated immigrants so that two thirds of workers with no schooling degree in California were foreign-born in 2004. If immigration harms the labor opportunities of natives, especially the least skilled ones, California was the place where these effects should have been particularly strong. But is it possible that immigrants raised the demand for California's native workers, rather than harming it? After all immigrants have different skills and tend to work in different occupations then natives and hence they may raise productivity and the demand for complementary production tasks and skills. We consider workers of different education and age as imperfectly substitutable in production and we exploit differences in immigration across these groups to infer their impact on US natives. In order to isolate the "supply-driven" variation of immigrants across skills and to identify the labor market responses of natives we use a novel instrumental variable strategy. Our estimates use migration by skill group to other U.S. states as instrument for migration to California. Migratory flows to other states, in fact, share the same "push" factors as those to California but clearly are not affected by the California-specific "pull" factors. We find that between 1960 and 2004 immigration did not produce a negative migratory response from natives. To the contrary, as immigrants were imperfect substitutes for natives with similar education and age we find that they stimulated, rather than harmed, the demand and wages of most U.S. native workers.
\end{abstract}

Giovanni Peri

Department of Economics

University of California, Davis

One Shields Avenue

Davis, CA 95616

and NBER

gperi@ucdavis.edu 


\section{Introduction}

In the year 2004, California was home to almost $30 \%$ of all foreign-born individuals working in the U.S.; in turn, these foreign-born represented roughly one third of the almost 15 million workers employed in California, two thirds of California workers without a high school degree and almost half of the California workers with a doctoral degree. Many U.S.-born Californians moved out of the state during the nineties and job competition from immigrants has sometimes been regarded as a key factor for this outflow. It stands to reason that if recent inflows of immigrants indeed crowded out the labor market options of U.S. natives, specifically the low skilled ones, then such an effect should have been particularly strong in California. But is it possible that immigrants actually lifted California's wages, rather than harming them? After all, immigrants have different skills and tend to work in different occupations than natives; they could make natives performing complementary production tasks more productive, thus increasing the demand for those tasks! The present study analyzes the effect of the migratory inflow on the employment, population and wages of U.S. natives in California, using data from the decennial U.S. Censuses and from the American Community Survey spanning the period 1960-2004.

Our approach combines elements of a "general equilibrium" (more structural) approach to immigration and wages, as proposed in recent national studies (Borjas 2003; Aydemir and Borjas 2007; Ottaviano and Peri, 2006) with the study of employment and inter-state migratory response of native workers typical of the so called "area approach" (exemplified in Card 1990, 2001, Lewis, 2005 and Borjas, 2006). As in Borjas (2003) we consider labor as a differentiated input in production and we model the interactions between workers with different education and age using a nested CES production function. As in Ottaviano and Peri (2006) we allow for imperfect substitution between native and foreign-born workers within an education-age group (due to differences in skills, occupational choices and job opportunities) and we estimate the elasticity of substitution between natives and immigrants. The degree of substitutability between these two groups is a key parameter to determine whether immigrants increase or depress the demand for native workers. For a large degree of substitutability between natives and immigrants, uneducated immigrants mostly depress the demand for uneducated natives and augment the demand for highly educated natives. However, for a smaller degree of substitutability between natives and immigrants, uneducated immigrants have a much smaller depressive effect on (and may even increase) the demand for uneducated natives while still increasing the demand for more educated natives.

As pointed out by the critics (e.g. Borjas et al, 1997) of the "area approach" when focussing on a state economy it is important to account for the fact that any labor market effect of immigration can be "diffused" to other states by out-migration of native workers. We carefully account for this effect in our empirical analysis. Moreover, by focussing on California over time, we are able to use a new identification strategy that addresses

the problems of unobserved demand shocks and measurement errors; these are often deemed responsible for biased estimates of the impact of immigration on the labor market outcomes of natives in a state (e.g. Aydemir 
and Borjas, 2006; Borjas, 2006). Specifically, we use immigration to the other U.S. states by skill group over decades as a reasonable instrument to proxy the "push"-driven component of immigration to California by skill group and decade. While sharing the "push" factors behind international migrations with California, the flows of foreign-born workers to other U.S. states are not affected by California's specific pull factors (i.e. unobserved demand shocks). The intuition of such identifying assumption is as follows. Suppose that immigrants with a college degree were "pulled" to California in the 90's by the boom in the high tech sector, which increased the demand for workers with their qualifications. This would be a "pull factor" specific to California. The same boom probably would also have attracted (or reduced the potential outflow of) natives in the same skill group. It could thus create a positive correlation between foreign immigration and natives' migration and wages - even if foreign migrants compete with natives for the same jobs. Such pull, however, would not be shared by other states and hence the instrument would not capture it. On the other hand take the cases of the increased international mobility of the college-educated Chinese middle-class or the worsened job outlook for young uneducated workers in Mexico during the nineties. Both are "push factors" that could increase immigration of some age-education groups to California (a large receiver of Chinese and Mexican migrants) as well as to other states. Push factors generate more migrants to California as well as to other states and are not related to changes in California's local demand for labor. Thus, how native employment responded to those immigration changes would correctly estimate how immigrants affect natives' employment opportunities - for a given local demand. The second purpose served by our instrument is to reduce the measurement error bias. As the measure of immigrants to other states is based on large national samples (excluding California), the instrument is also largely exempt from the measurement error affecting state-level measures of immigration by skill due to the potentially small size of cells ${ }^{1}$. Hence, we have an instrument for the inflow of immigrants that is potentially uncorrelated (or weakly correlated) with California-specific labor demand shocks and the measurement errors while still correlated with the supply-driven shocks to the composition of immigrants to California. This instrumental variables strategy that we adopt is novel for the "area" approach and it is an improvement on the "national" approach (e.g. Borjas, 2003) in that, while we cannot rely on some natural experiment, we have a more sophisticated way of isolating supply-driven variations of immigrants going beyond the simple inclusion of education-age, education-year and age-year specific effects (which we still include).

The rest of the paper is organized as follows: Section 2 presents the data and shows some statistics on the skills of foreign-born and recent immigrants to California. Section 3 presents the production function used as framework to estimate the effect of immigration on wages. The skill-structure defined in the production function is used in the empirical estimations. Section 4 presents the identifying strategy and shows the migration and employment responses of California's native workers to immigration for the period 1960-2004. Section 5

\footnotetext{
${ }^{1}$ Recent work by Aydemir and Borjas (2006) analyzes the role of measurement error in generating potential bias in the estimates of the impact of immigrants based on local data.
} 
estimates the substitutability between U.S. and foreign born workers within education-age groups. Section 6 uses the estimated parameters to calculate the effects of immigrants on wages of natives (by education) for the 1990-2004 period. Section 7 concludes.

\section{Immigration to California: A Look at the Data}

The data we use are from the integrated public use microdata samples (IPUMS) of the U.S. decennial Census and of the American Community Survey (Ruggles et al, 2005). In particular, we use the general (1\%) sample for Census 1960, the 1\% state sample, Form 1, for Census 1970, the 5\% state sample for the Censuses 1980 and 1990, the 5\% Census sample for year 2000 and the 1/239 American Community Survey (ACS) Sample for the year 2004. As those are all weighted samples we use the variable "personal weight" to construct all the average and aggregate statistics relative to California. We consider people aged 17 to 66 not living in group quarters, and we included them among the workers if they worked at least one week in the previous year and earned a positive amount in salary income. When using wage data, we converted the current wages to constant wages (in 2000 U.S. \$) using the CPI (Consumer Price Index)-based deflator across years. We define the four schooling groups using the variable that identifies the highest grade attended (called "HIGRADEG" in IPUMS) for census 1960 to 1980 while we use the categorical variable (called "edu99" in IPUMS) for censuses 1990 and 2000 and ACS 2004. Age groups are identified using the variable "AGE". Finally, yearly wages are based on the variable for salary and income wage (called "INCWAGE" in IPUMS). Weekly wages are obtained dividing that value by the number of weeks worked ${ }^{2}$. The status of "foreign-born" is given to those workers whose place of birth (variable "BPL") is not within the USA (or its territories overseas) and did not have U.S. citizenship at birth (variable "CITIZEN") ${ }^{3}$

Table 1 illustrates the evolution of the percentage of foreign born in employment and population for the period 1960-2004. Employment is defined as the sum of individuals aged 17 to 66 years old, not residing in group quarters, who worked at least one week in the previous year. Population is defined as the sum of individual between 17 and 66 years of age not residing in group quarters. We report the figures for California as compared to the corresponding figures for the whole U.S.A. First, note that in California the percentages of foreign-born already began growing in the sixties, while in the U.S. as a whole they only began to grow during the seventies. During the seventies, eighties and nineties, California experienced increases in the share of foreign-born workers by about $7 \%$ in each decade, with similar rates continuing after the year 2000; in the whole U.S., the increases were far more modest over that period, amounting to 2-3\% per year. Second, over the entire period considered,

\footnotetext{
${ }^{2}$ For Census 1960 and 1970 only a categorical variable that measures weeks worked exists, called "WKSWRK2". Individuals are assigned the middle value of the interval in the variable.

${ }^{3}$ The variable CITIZEN is not available in Census 1960. For that year we consider all people born outside the U.S. as foreignborn.
} 
the share of foreign-born workers in employment was larger than their share of population, denoting higher employment/population ratios of immigrants relative to natives; this was due in part to their age distribution. Finally, notice that the percentage of immigrants in California's population and employment as of 1980 is similar to the percentage of immigrants in population and employment for the nation in 2004. In terms of percentages, a continuation of the present trend would imply that the future of the nation may look like the last 25 years of California's experience.

Moreover, in addition to their percentages of population and employment, the distribution of foreign-born across education levels in California in 1980 is similar to that for the whole nation in 2004. Table 2 shows the percentage of foreign-born workers in California by education group between 1960 and 2004. Notice the higher concentration of foreign-born among the low (less than high school) and high (college or more) schooling levels and the lower concentration in the intermediate education levels. Notice that, as of 2004, two thirds of high school dropout workers in California were immigrants as well as $42 \%$ of Ph.D.'s, while only $20 \%$ of workers with some college education but no degree were not U.S. born. The distribution of immigrants, predominantly at the two ends of the schooling spectrum, will be dubbed "U-shaped". This U-shape is also a feature of the national data; Figure 1 shows the percentage of foreign-born workers by education level in 2004, comparing California and the whole U.S. One clearly notices the same qualitative U-shaped distribution, but each bar is much higher for California, denoting a higher average percentage of foreign-born. We need to go back to the year 1980 (see Table 2) to find percentages of foreign born across education groups in California similar to the ones for the U.S. today: back then, in California, $32 \%$ of high school dropouts, $12 \%$ of high school graduates, $10 \%$ of college dropouts $^{4}$ and $14 \%$ of college graduates were foreign-born.

The numbers presented above are relative to the "stock" of foreign-born living in California (or nationally). The more recent flow of immigrants to California and to the U.S. (1990-2004) also has a similar distribution over schooling. Figure 2 shows the net growth in employment due to immigrants as percentage of initial employment by education group for California (light shaded columns) and for the U.S. as a whole (dark shaded columns). College graduates, Masters and Ph.D.'s flowed in much larger percentages of initial employment in the group than college dropouts both in California and the whole U.S. At the opposite end of the schooling spectrum, the inflow of high school dropouts was much larger as a percentage of the group than inflow of high school graduates. Overall, aggregating across groups, immigrants to California during the 1990-2004 period equaled $20 \%$ of its total employment in 1990 , while in the U.S. as a whole they were only $11 \%$ of initial employment. These aggregate numbers provide a good sense of how large immigration has been in California.

The focus of this paper is the effect of immigration on the labor market outcomes of Californian workers. It is useful, therefore, to start by showing the behavior of native worker real wages during the most recent fourteen

\footnotetext{
${ }^{4}$ For brevity, and somewhat improperly, we often use the term "College Dropouts" to indicate those people who have some College education but not a four-year degree.
} 
years of data (1990-2004); these years correspond to the period of largest immigration flows. Figure 3 shows the percentage change in real wage for native workers, by education group, in California (light shaded columns) and in the U.S. as a whole (dark shaded columns) for the 1990-2004 period. We use real weekly wages calculated as yearly wage and salary income divided by weeks worked, and convert to constant 2000 dollars by dividing for the Consumer Price Index deflator. First of all, we notice that the real wage changes across education groups are very similar in California compared to the whole nation; the difference in real wage growth between California and the rest of the nation was never larger than $4 \%$ in any group. In terms of magnitude across education groups, high school dropouts' wages decreased in real terms over the period by as much as $17 \%$, real wages of high school graduates were rather stationary, while real wages of college graduates and above experienced a substantial increase, generally above $20 \%$. Aggregating across groups, the average real wage grew by $10.7 \%$ in California and by $9.7 \%$ in the U.S. as a whole, again denoting a similar performance (less than $0.1 \%$ difference in growth per year), with no apparent wage "penalty" at all for the high-immigration state of California.

California's closeness to the national average in terms of wage dynamics over the last 15 years denotes substantial integration of the Californian labor market with the rest of the U.S. Implied are small costs of moving that arbitrage away large differences in wage changes across states. The poor performance of uneducated worker real wages, contributing to an increase in wage dispersion and income inequality, has certainly been a thorny issue in California as well as in the rest of the nation. The question is whether it was immigration flows that contributed to these real wage changes in California and the U.S. and by how much.

\section{The Framework: Production Function and Imperfect Substitutabil- ity}

To evaluate the effects of immigrants on the wages and employment of native workers in California we use a framework similar to Ottaviano and Peri (2006). Workers differ by their education and age; different types of workers and physical capital are combined in a production function to produce output. The marginal productivity (wage) of each group depends on skill-specific technology and the supply of each group is affected by immigration. We extend that framework to allow for changes in the labor supply of natives (via migration to/from other states and in/out of employment) in response to immigration, and we estimate these responses and corresponding wage elasticities maintaining the same groupings by skill in the production function. Then, we use the estimated responses and the estimated wage elasticities to calculate the overall effect of immigration on the wages of U.S. natives in California. 


\subsection{Production Function}

Following previous work with Gianmarco Ottaviano (Ottaviano and Peri, 2006) that, in turn, builds on Borjas (2003), we represent output in California as produced by physical capital and different types of labor. Labor types are grouped according to education and age and combined in a constant elasticity of substitution (CES) aggregate; age groups are nested within educational groups that are themselves nested into the labor composite $L_{t}$. U.S.-born and foreign-born workers are allowed a further degree of imperfect substitutability even when they have the same education and age. More specifically, the aggregate production function is given by the following expression:

$$
Y_{t}=A_{t} L_{t}^{\alpha} K_{t}^{1-\alpha}
$$

where $Y_{t}$ is aggregate output, $A_{t}$ is total factor productivity (TFP), $K_{t}$ is physical capital, $L_{t}$ is a CES aggregate of different types of labor (described below), and $\alpha \in(0,1)$ is the income share of labor. All variables reflect data for the state of California in year $t$. The labor aggregate $L_{t}$ is defined as:

$$
L_{t}=\left[\sum_{k=1}^{4} \theta_{k t} L_{k t}^{\frac{\delta-1}{\delta}}\right]^{\frac{\delta}{\delta-1}}
$$

where $L_{k t}$ is an aggregate measure of workers with educational level $k$ in year $t ; \theta_{k t}$ are education-specific productivity levels (standardized so that $\sum_{k} \theta_{k t}=1$ and thus any common multiplying factor can be absorbed in the TFP term $A_{t}$ ). We group educational achievements into four categories: high school dropouts (denoted as $H S D)$, high school graduates $(H S G)$, college dropouts $(C O D)$ and college graduates $(C O G)$, so that $k=$ $\{H S D, H S G, C O D, C O G\}$. The parameter $\delta>0$ measures the elasticity of substitution between workers with different educational achievements. Within each educational group we allow workers with different experience levels to be imperfect substitutes. In particular, following the specification used in Card and Lemieux (2001), we write:

$$
L_{k t}=\left[\sum_{j=1}^{5} \theta_{k j} L_{k j t}^{\frac{\eta-1}{\eta}}\right]^{\frac{\eta}{\eta-1}}
$$

where $j$ is an index spanning age intervals of ten years between 17 and 66 , so that $j=1$ captures workers 17-26 years old , $j=2$ captures those who are 27-36 years old, and so on. Within an education group age groups are identical to groups based on years of experience and sometimes we will use the terms "age" and "experience" interchangeably. The reason to choose a ten year interval is that, by so doing, we can track ten year cohorts across censuses and control for their demographic tendencies when evaluating the impact of immigration on employment, revealing the internal migratory response of natives to foreign immigrants. The parameter $\eta>0$ measures the elasticity of substitution between workers in the same education group with different experience 
levels and $\theta_{k j}$ are experience-education specific productivity levels (standardized so that $\sum_{j} \theta_{k j}=1$ for each $k$ and assumed to be invariant over time, as in Borjas, 2003). As we expect workers within an education group to be closer substitutes than workers across different education groups, our prior (consistent with other findings in the literature) is that $\eta>\delta$. Finally, we define $L_{k j t}$ as a CES aggregate of home-born and foreign-born workers. Denoting the number of workers with education $k$ and experience $j$ who are, respectively, home-born and foreign-born, with $H_{k j t}$ and $F_{k j t}$, and the elasticity of substitution between them by $\sigma>0$, our assumption is that:

$$
L_{k j t}=\left[\theta_{H k j t} H_{k j t}^{\frac{\sigma-1}{\sigma}}+\theta_{F k j t} F_{k j t}^{\frac{\sigma-1}{\sigma}}\right]^{\frac{\sigma}{\sigma-1}}
$$

Foreign-born workers are likely to have different abilities pertaining to language, quantitative skills, relational skills and so on. These characteristics, in turn, are likely to affect their comparative advantages in production and hence choices of occupation, therefore foreign-born workers should be differentiated enough to be treated as imperfect substitutes for U.S.-born workers, even within the same education and experience group. While in a more general specification the substitutability between U.S.- and foreign-born workers, $\sigma$, may vary across education groups $(k)$, the findings in Ottaviano and Peri (2006) suggest that those differences are not very relevant; hence, herein we maintain a common elasticity. Finally, the terms $\theta_{H k j t}$ and $\theta_{F k j t}$ measure the specific productivity levels of foreign- and home-born workers, and they may vary across groups and years (in the empirical identification we impose a systematic structure on their variations over time) . They are also standardized so that $\left(\theta_{H k j t}+\theta_{F k j t}\right)=1$.

\subsection{Effects of Immigration on Employment and Wages in a State Economy}

Using the production function (1) we can calculate the wage response of each group to total immigration once we know the parameters $\delta, \eta$ and $\sigma$, and have the data on immigration flows, wage shares and employment. In particular, assuming a given supply of U.S.-born workers in each skill group, $H_{k j t}$, and assuming that physical capital adjusts to immigration so as to keep its real return constant, one can easily show that the effect of total immigrants on the real wages of U.S. natives of education $k$ and experience $j$ (expressed in units of output $Y_{t}$, which is taken as the numeraire) is given by the following expression:

$$
\begin{aligned}
\left(\frac{\Delta w_{H k j t}}{w_{H k j t}}\right)^{\text {Total }}= & \frac{1}{\delta} \sum_{m} \sum_{i}\left(s_{F m i t} \frac{\Delta F_{m i t}}{F_{m i t}}\right)+\left(\frac{1}{\eta}-\frac{1}{\delta}\right)\left(\frac{1}{s_{k t}}\right) \sum_{i}\left(s_{F k i t} \frac{\Delta F_{k i t}}{F_{k i t}}\right)+ \\
& +\left(\frac{1}{\sigma}-\frac{1}{\eta}\right)\left(\frac{1}{s_{k j t}}\right)\left(s_{F k j t} \frac{\Delta F_{k j t}}{F_{k j t}}\right)
\end{aligned}
$$


and the effect of immigration on wages of foreign-born (previous immigrants) of education $k$ and experience $j$ is given by:

$$
\begin{aligned}
\left(\frac{\Delta w_{F k j t}}{w_{F k j t}}\right)^{\text {Total }}= & \frac{1}{\delta} \sum_{m} \sum_{i}\left(s_{F m i t} \frac{\Delta F_{m i t}}{F_{m i t}}\right)+\left(\frac{1}{\eta}-\frac{1}{\delta}\right)\left(\frac{1}{s_{k t}}\right) \sum_{i}\left(s_{F k i t} \frac{\Delta F_{k i t}}{F_{k i t}}\right)+ \\
& +\left(\frac{1}{\sigma}-\frac{1}{\eta}\right)\left(\frac{1}{s_{k j t}}\right)\left(s_{F k j t} \frac{\Delta F_{k j t}}{F_{k j t}}\right)-\frac{1}{\sigma} \frac{\Delta F_{k j t}}{F_{k j t}}
\end{aligned}
$$

The term $\frac{\Delta F_{k j t}}{F_{k j t}}$ is the percentage change of foreign-born in skill group $k, j$ due to immigration; the variable $s_{F k j t}$ is the wage share paid in year $t$ to foreign workers in group $k, j$, namely $s_{F k j t}=\frac{w_{F k j t} F_{k j t}}{\sum_{m} \sum_{i}\left(w_{F m i t} F_{m i t}+w_{H \text { mit }} H_{m i t}\right)}$. Analogously, $s_{k j t}=\frac{w_{F k j t} F_{k j t}+w_{H k j t} H_{k j t}}{\sum_{m} \sum_{i}\left(w_{F m i t} F_{m i t}+w_{H m i t} H_{m i t}\right)}$ is the share of wage income in year $t$ paid to all workers in skill group $k, j$. While appropriate when considering the overall U.S. economy, the assumption of fixed labor supply of natives, $H_{k j t}$, may not hold when we analyze the effect of immigrants on a state economy. In response to an inflow of immigrants, $\Delta F_{k j t}$, native workers may move out of or be attracted to California, depending on the effect of a larger supply of immigrants on the demand for natives. We denote as $\left(\frac{\Delta H_{k j t}}{H_{k j t}}\right)_{\text {response }}$ the percentage change of native employment of education $k$ and age $j$ in period $t$ in response to total immigration during period $t$, and we need to account for this response when evaluating the overall effect of immigration on wages. It is easy to show that, in this case, the long-run effect of immigration on the wages of natives and foreign-born would be given by the following two expressions:

$$
\begin{aligned}
\left(\frac{\Delta w_{H k j t}}{w_{H k j t}}\right)^{\text {Total }}= & \frac{1}{\delta} \sum_{m} \sum_{i}\left(s_{F m i t} \frac{\Delta F_{\text {mit }}}{F_{\text {mit }}}+s_{\text {Hmit }}\left(\frac{\Delta H_{m i t}}{H_{\text {mit }}}\right)_{\text {response }}\right)+ \\
& \left(\frac{1}{\eta}-\frac{1}{\delta}\right)\left(\frac{1}{s_{k t}}\right) \sum_{i}\left(s_{F k i t} \frac{\Delta F_{k i t}}{F_{k i t}}+s_{H k i t}\left(\frac{\Delta H_{k i t}}{H_{k i t}}\right)_{\text {reponse }}\right)+ \\
& +\left(\frac{1}{\sigma}-\frac{1}{\eta}\right)\left(\frac{1}{s_{k j t}}\right)\left(s_{F k j t} \frac{\Delta F_{k j t}}{F_{k j t}}+s_{H k j t}\left(\frac{\Delta H_{k j t}}{H_{k j t}}\right)_{\text {response }}\right) \\
& -\frac{1}{\sigma}\left(\frac{\Delta H_{k j t}}{H_{k j t}}\right)_{\text {response }}
\end{aligned}
$$




$$
\begin{aligned}
\left(\frac{\Delta w_{F k j t}}{w_{F k j t}}\right)^{\text {Total }}= & \frac{1}{\delta} \sum_{m} \sum_{i}\left(s_{F m i t} \frac{\Delta F_{m i t}}{F_{m i t}}+s_{H m i t}\left(\frac{\Delta H_{m i t}}{H_{m i t}}\right)_{\text {response }}\right)+ \\
& +\left(\frac{1}{\eta}-\frac{1}{\delta}\right)\left(\frac{1}{s_{k t}}\right) \sum_{i}\left(s_{F k i t} \frac{\Delta F_{k i t}}{F_{k i t}}+s_{H k i t}\left(\frac{\Delta H_{k i t}}{H_{k i t}}\right)_{\text {reponse }}\right) \\
& +\left(\frac{1}{\sigma}-\frac{1}{\eta}\right)\left(\frac{1}{s_{k j t}}\right)\left(s_{F k j t} \frac{\Delta F_{k j t}}{F_{k j t}}+s_{H k j t}\left(\frac{\Delta H_{k j t}}{H_{k j t}}\right)_{\text {response }}\right) \\
& -\frac{1}{\sigma} \frac{\Delta F_{k j t}}{F_{k j t}}
\end{aligned}
$$

The terms containing $\frac{\Delta F_{k j t}}{F_{k j t}}$ are identical to those in the formulas (5) and (6). The terms containing $\left(\frac{\Delta H_{k i t}}{H_{k i t}}\right)_{\text {response }}$ account for the wage shift due to the change in native supply of labor in response to immigration. If the induced adjustment of native employment has the opposite sign of the change in foreign-born due to immigration and a relevant magnitude, accounting for it will attenuate the impact of immigration on wages. On the other hand, if the induced adjustment is negligible accounting for it will not significantly change the impact on wages obtained by the simple application of (5) and (6). The next section describes how we estimate the response of native employment to immigrants, $\left(\frac{\Delta H_{k i t}}{H_{k i t}}\right)_{\text {response }}$, and the instrumental variable strategy behind those estimates.

\section{The Response of Native Labor Supply}

\subsection{Specification and Instrumental Variables}

While we do not model in detail the mechanism producing the response of native employment to immigration, we estimate the elasticity of $H_{k j t}$ (i.e. the supply of natives in an education experience group) to changes in $F_{k j t}$ by running the following regression:

$$
\frac{\Delta H_{k j t}}{H_{k j t}+F_{k j t}}=D_{k j}+D_{k t}+\vartheta \frac{\left(\Delta H_{k j t}\right)^{\text {natural }}}{H_{k j t}+F_{k j t}}+\gamma \frac{\Delta F_{k j t}}{H_{k j t}+F_{k j t}}+u_{k j t}
$$

$\Delta H_{k j t}$ is the change in native employment in cell $k, j$ during the decade $t$. The left hand side of (9) measures the change in native employment as a percentage of overall initial employment in the skill group $k, j: H_{k j t}+F_{k j t}$. The regression controls for education by age $\left(D_{k j}\right)$ and education by year $\left(D_{k t}\right)$ fixed effects. These controls are supposed to capture systematic differences in employment growth across skill groups as well as those that are education-decade specific; for instance, the latter could potentially be due to skill-biased productivity changes. We also control for the predicted change of employment in each cell, denoted $\left(\Delta H_{k j t}\right)^{\text {natural }}$, that accounts 
for demographic trends (cohort size and mortality rates) and national employment/population ratios ${ }^{5}$. Any deviation of $\Delta H_{k j t}$ from the predicted change $\left(\Delta H_{k j t}\right)^{\text {natural }}$ in employment is due either to net migration to/from other states or changes in the employment/population ratio of the group ${ }^{6}$. The coefficient $\gamma$ captures the elasticity of native employment changes, $\Delta H_{k j t}$, to immigration flows, $\Delta F_{k j t}$. $u_{k j t}$ are zero-mean cellspecific shocks. Once we have an estimate of the elasticity $\gamma$, we can obtain the response of native employment to immigration, used above as $\left(\frac{\Delta H_{k i t}}{H_{k i t}}\right)_{\text {response }}=\gamma\left(\frac{\Delta F_{k j t}}{F_{k j t}}\right)\left(\frac{F_{k j t}}{H_{k j t}}\right)$.

In order to obtain an estimate of the coefficient $\gamma$ that captures the response of native labor supply to immigration in California we adopt the following estimation and identification strategy. First, as already noted, we control for education-specific labor demand shocks $\left(D_{k t}\right)$, that would induce correlation between the residual and the immigrants' inflow. Second, we perform an instrumental variables estimation using the variable $\frac{\Delta F_{k j t}}{H_{k j t}+F_{k j t}}$ over skill groups and decades calculated for the rest of the U.S. as an instrument for immigration flows to California. The flows of immigrants to any U.S. state by education and experience groups are determined by the interaction of "push" (supply) factors, relative to the countries of origin of immigrants and "pull" (demand) factors specific to the U.S. states where they move to. By using immigration by skill in the rest of the U.S. as an instrument for its counterpart in California we are able to isolate the supply-driven variation of immigration (common for flows to California and rest of the U.S.) from the demand-driven variation specific to California. Furthermore, if the dependent variable is measured with error due to the fact that the size of some skill cells in California is small and the $1 \%$ samples used may have a non-trivial measurement error, the instrument, based on national data (excluding California) is likely to have larger size in all cells and to measure immigration much more precisely as a percentage of initial employment. This would drastically reduce any measurement error bias. In general, using migration by cell for the rest of the country as an instrument, we rely on the fact that the education-age distribution of immigrants to California is correlated to the distribution for the rest of the U.S. due to common countries of origin and push-factors. For instance, scant job opportunities for young uneducated workers in Mexico during the nineties was a supply factor inducing a large $\Delta F_{k j t}$ for low education, young age groups, both for California and the U.S. as a whole. On the other hand, good employment opportunities for middle aged, highly educated engineers in Silicon Valley would certainly affect $\Delta F_{k j t}$ in some education-age groups in California, but would not affect $\Delta F_{k j t}$ for the same groups in the rest of the country. These "pull" factors, that also affect $\Delta H_{k j t}$ for California, and induce correlation between $\Delta F_{k j t}$ and $u_{k j t}$, would not affect the instrument. To our knowledge, this method isolating "pull" factors that determine migration to California, is novel to the area approach. At the same time, it is an improvement on the existing aggregate literature that adopts a similar CES production structure (Borjas 2003; Borjas and Katz, 2005; Ottaviano and Peri, 2006) and

\footnotetext{
${ }^{5}$ The construction of $\left(\Delta H_{k j t}\right)^{\text {natural }}$ is described in detail in Section 4 below.

${ }^{6}$ Faster or slower educational upgrading relative to the rest of the nation could also be a cause of deviation. However, we also run the regressions using only age groups over 27 years, which reduces the extent of educational upgrading of a cohort over time (as most people have their final degree by age 27 ), obtaining very similar results.
} 
simply assumes that, once education by year effects are accounted for, the remaining variation of immigration over time in a skill group is supply-driven.

Once we obtain its estimate, the interpretation of the coefficient $\gamma$ is very simple. If it is equal to negative one, it implies that for each immigrant moving to California one native moves out of the state; that is, immigrants fully displace natives. On the contrary, a coefficient $\gamma$ equal to 0 , would imply that natives' employment is not affected at all by immigration. Finally, a positive estimate of $\gamma$ implies that immigrants are complementary enough to native workers to augment their productivity, create new business opportunities for them and consequently increase their demand and attract new workers to the state. In order to identify the cross-state migration response, we run specification (9) using population measures. In order to focus more specifically on employment effects, we also run some specifications using employment and employment ratios (by education and age) as dependent variables in regressions similar to (9).

Finally, recall that $\gamma$ estimates a relative response to immigration. Specifically, $\gamma$ measures the percentage change in native employment of group $k, j$ in response to immigration in that group relative to changes in other experience groups within the same education group $k$. Maintaining the "nested" structure described in section 1 we also estimate a response to immigration within entire education groups, $\gamma_{E D U}$ as follows:

$$
\frac{\Delta H_{k t}}{H_{k t}+F_{k t}}=D_{k}+\operatorname{Trend}_{k}+\vartheta_{1} \frac{\left(\Delta H_{k t}\right)^{\text {natural }}}{H_{k t}+F_{k t}}+\gamma_{E D U} \frac{\Delta F_{k t}}{H_{k t}+F_{j t}}+u_{k t}
$$

where the variables have been aggregated across experience within education groups so that: $\Delta H_{k t}=\sum_{j} \Delta H_{k j t}$, $H_{k t}=\sum_{j} H_{k j t}, F_{k t}=\sum_{j} F_{k j t}$ and $\left(\Delta H_{k t}\right)^{\text {natural }}=\sum_{j}\left(\Delta H_{k j t}\right)^{\text {natural }}$. We allow fixed education effects $D_{k}$ and education-specific trends Trend $_{k}$ to account for aggregate factors and skill-specific technological progress.

As before, we estimate $\gamma_{E D U}$ using the variable $\frac{\Delta F_{k t}}{H_{k t}+F_{j t}}$ for the rest of the U.S. as an instrument for the corresponding migration to California.

\subsection{Estimates}

Table 3 shows the estimates of the coefficients $\gamma$ (first row) and $\vartheta$ (second row) in regression (9). The change in native employment as a percentage of the initial employment (by cell) is regressed on the change in foreign-born employment (also as a percentage of initial employment), on the predicted change in native employment and on a set of dummies that control for education by age fixed effects and education by year fixed effects. The predicted inter-census change in employment of an education-age group is calculated using the population of that group ten years earlier and applying to it the nationwide mortality rate of that group over a decade, as well as the national employment rate for that group in that census year. We also correct for the possibility of education upgrading, i.e. that people in a certain education-cohort cell move to a higher education cell, using the national upgrading rate by cohort. After 27 years of age, however, the percentage of workers upgrading 
their skills by further formal education is very small and the results are very similar wether we account for them or not. Hence, for instance, the population of U.S. natives in the cohort of high school educated individual, 37 to 46 years old in 1960 is used to predict the population of U.S. natives in the cohort of high school educated individuals, 47 to 56 years old in 1970. Then, the national employment rate for U.S. natives in the 47-56 years old group in 1970 is applied to obtain the predicted employment for that cohort in 1970. Any differences between the actual and the predicted change in population are due to changes of native individuals in the cohort due to cross-state migration. Any differences between actual and predicted employment changes are due either to cross-state migrations or to changes in the state employment/population ratios relative to the national ones.

We use ten-year age groups (five of them, between 17 and 66 years of age) and four educational attainments over four decades 1960-2000, for a total of 80 observations. After having analyzed the overall effect of immigration on native employment (Table 3) we also analyze its components by looking separately at population, only affected by migration of natives in- or out-of-state (Table 4), and employment/population ratios, only affected by higher or lower participation into the labor market (Table 5). Regressions in Table 3 also include education by age fixed effects that account for systematic differences across groups and education by year fixed effects that account for education-specific shocks to labor demand. The basic specification 1 of Table 3 estimates the panel by weighted least squares, using employment of each cell as its weight, specification 2 performs simple least squares estimation, specification 3 omits the education by year effects and specification 4 uses only data from the two groups with lower education (high school graduates and high school dropouts). The elasticity of native employment to immigration ( $\gamma$ in equation 9 ) is consistently estimated at around 0.10 , not significantly different from 0 but usually significantly larger than -0.1 . This implies that the estimates rule out even a very modest out-migratory response of natives or employment loss of natives to immigrants (such as -0.10): native workers' employment is unaffected by immigrants. Such a feature is robust across specifications, and in particular, also holds for the groups with lowest education (see specification 4). In order to check whether omitted demandshock-bias plus measurement error bias affects the OLS estimates, specification 5 to 8 re-estimate regressions1 to 4 using migration by skill to the rest of the U.S. (discussed above) as an instrument. The first stage of the regression (reported in the lower portion of Table 3) reveals that the instrument has power. Moreover it reveals that the instrument has a positive correlation with the explanatory variable. This implies that migrations to other states and to California, are positively related, as it is implied by our assumption that they share the same "push" determinants. To the contrary, if the correlation arose because migrants are attracted to other states by pull factors and "taken away" from California then it would be negative. In some specifications, however, such as when we restrict the consideration to the lowest education groups, the first stage correlation may not be very strong (F-test of 7.5). The most relevant finding, robust across specifications, is that the IV estimates of the elasticity $\gamma$ are insignificantly different from their OLS counterparts, are positive and are not different 
from 0 at any standard significance level. Standard errors of the IV estimates are about three times as large as those of their OLS counterparts, and the IV point estimates are generally positive and larger in absolute value than the OLS ones, implying that the unobserved demand shock does not seem to bias the OLS estimates upwards. Using our method to isolate supply-driven shocks to immigration we do not detect any negative effects on native employment. The size of standard errors makes inference less precise with the IV estimates, but in general even a modest negative effect (such as -0.30) can be ruled out at standard confidence levels. Notice, on the other hand, that the coefficient on the predicted employment change is always positive, close to one and very significant. This means that the local demographic tendencies (affecting supply) are very important to predict employment changes by skill in California.

Tables 4 and 5 reproduce the analysis and the specifications of Table 3, considering respectively population and employment/population ratios as dependent variables. The fact that we do not find any significant effects of immigration on changes in native employment suggests that we should not find any significant effect on the individual components of this change: population change due to cross-state migration and changes in employment/population ratios. In fact, the elasticities of these two variables to immigration are also estimated to be insignificantly different from 0: around 0.14 (median estimate in Table 4) for native population and around 0.05 (median estimate in Table 5) for native employment rates. The specifications estimated in these tables are identical to those in Table 3: the weighted least squares specification in column 1, the unweighted OLS in column 2, a specification omitting education by year dummies in column 3 and including only the groups of high school graduates and high school dropouts in column 4. Most of the time we are able to rule out modest negative effects on the order of -0.20 for the population change and on the order of -0.05 for the employment rate change. Native population change in a group seems to be predicted particularly well by the local demographics (cohort size) as the coefficients on the predicted change in the second row of Table 4 are all close to one and very precisely estimated. Similarly, the national employment/population ratios are very good predictors of the California employment/population ratios (second row of Table 5). Notice also that the reaction of the least educated native groups to immigrants is not different from the reaction of the other groups, neither for population nor for employment. The general tendencies of the IV estimates (specifications 4 and 8 in tables 4 and 5) also confirm the finding of Table 3: they are somewhat more imprecise than the OLS ones but never significantly different from those estimates or from 0 , and are never in the negative range.

The skill structure assumed in production, implying higher substitutability between workers with the same education and age allows us to use age by education groups to estimate the relative elasticity $\gamma$, controlling for education by year effects. Native workers, however, may be exposed to competition from other age groups in the same education attainment group, and such competition may also affect cross-state migration and the employment of natives. Therefore we estimate specification (10), which aggregates age groups in each education 
category to obtain the elasticity of native employment to the flow of immigrants in the same education group, $\gamma_{E D U}$. We control for the predicted change in employment of the group, and for education-specific trends and education fixed effects. Table 6 presents the estimates of four different specifications using, respectively, simple and weighted least squares (specifications 1 and 2) and simple and weighted 2SLS (specifications 3 and 4) with migration to other states as an instrument. The drawback of these specifications is that, as we are aggregating over age groups, we only have 16 observations (education group by census) and hence we are not able to obtain precise estimates. Even in this case, however, employment of natives does not respond significantly to immigrant flows in the same education group. The estimates of $\gamma_{E D U}$ are positive, between 0.08 and 0.17 with standard errors around 0.2 ; they are consistent with native employment not responding to immigration. The large standard errors only allows us to rule out negative effects on the order of -0.3 to -0.4 , both for the least squares and IV estimations. We never find negative point estimates of $\gamma_{E D U}$, however, so it seems quite reasonable to infer a zero response (rather than a negative response) of native employment to immigration within the same schooling group.

Finally, Table 7 estimates the reaction of native employment to immigration by age group. While the production function in section 3.1 suggests that age is "nested" into schooling as a worker's attribute (hence the correct groupings are those analyzed in Tables 3 to 6), one may think that workers of the same age compete more directly with each other as they enter the labor market in the same period despite different educational attainments, or may have parallel career paths ${ }^{7}$. Table 7 consider 5 age groups (17 to 66) over four census years 1960-2000, and the responses of employment (column 1 and 3) and employment/population ratios (column 2 and 4) of natives to immigrants, controlling for age group effects and age-group trends. The estimates in the first row, obtained via least squares (specifications 1 and 2) and 2SLS (specifications 3 and 4) show once more no significant effect and positive point estimates. This time the standard errors are quite large (up to 0.80) while the point estimates range between 0.08 and 0.70 . While not very informative by themselves, due to the imprecision of the estimates, the results of Table 7 provide no evidence of migratory response of natives to immigrants and hence they do not provide any reason to doubt the previous estimates. There is very little or no reaction of native employment to immigration for workers in the same age group, either via cross-state migration or via changes in employment/population ratios, just as was the case for education by age and education groupings.

\section{Substitutability Between Native and Foreign-Born Workers}

Summing up the evidence from section 4 above we find an insignificant reaction of native employment/population to immigration. This may be due to a combination of small wage effects of immigrants on natives and small

\footnotetext{
${ }^{7}$ A closer substitutability within age groups would stem from a different type of nesting in the CES production function (i.e. with education groups nested within age groups).
} 
moving costs. Gross migration rates between U.S. states are rather large. About one third of Americans moved between states in the decade 1990-2000. While there are certainly costs of moving, it is hard to believe that native workers would not move in the face of large potential wage losses due to immigration. How can we calculate the wage effects of immigrants in order to check whether their size is consistent with a very small migratory reaction? Following the framework described in section 3.1 we can use the production function and the parameters $\delta, \eta$ and $\sigma$, estimated from the national economy, to evaluate the effect of immigrants on the wages of each skill group in California. We can also aggregate those changes across age groups to obtain the effects for each education group of native and foreign-born workers. As the native supply in each group $H_{j k t}$ does not seem to be systematically affected by immigration we can use the more basic formulas (5) and (6) to obtain these effects. Previous estimates of $\delta$ and $\eta$ at the national level are relatively standard and robust across studies, with values of $\delta$ in the proximity of 2 (Katz and Murphy, 1992; Hamermesh, 1993; Angrist, 1995; Ciccone and Peri, 2005) and values of $\eta$ around 4 (Borjas, 2003, Card and Lemieux, 2001, Ottaviano and Peri, 2006). Hence, we use those values in this study without further ado. The estimates of the parameter $\sigma$, however, are more controversial. Moreover, they are crucial in evaluating the degree of substitutability between U.S.-and foreign-born workers with important implications for the effect of immigration on the wages of natives. Ottaviano and Peri (2006a) estimate this parameter to range between 5 and 10 (median value 6.6) using national U.S. data, Manacorda et al. (2006) applying the same framework to British data estimate a value of $\sigma$ for the U.K. of between 4 and 6.6. Our specification and the results of the previous section, however, allow us to re-estimate $\sigma$ using California data. As we established that native labor supply $H_{k j t}$ does not respond systematically to immigration, one can use variation to the supply of foreign-born, $F_{k j t}$, and the following relationship between marginal productivity and employment to estimate $\sigma$; this equation is derived from the production function in section 3.1, using the assumption that wages equal the marginal productivity of workers:

$$
\ln \left(w_{H k j t} / w_{F k j t}\right)=D_{k j}+D_{k t}+D_{j t}-\frac{1}{\sigma} \ln \left(H_{k j t} / F_{k j t}\right)+u_{k j t}
$$

Equation (11) shows that the response of log relative weekly wages (U.S.- and foreign-born) to log relative employment, once we account for education by age, education by time and age by time fixed effects, identifies the inverse (with a negative sign) of the elasticity of substitution between U.S. and foreign-born workers in production. The advantage of estimating this regression with California data is that we can use the variable $F_{k j t}^{U S}$ constructed for the rest of the nation as an instrument for $F_{k j t}$, immigration by skill to California. The decade changes in the instrumental variable, correlated to the supply-side determinants of migration and not to the California-specific demand side and precisely measured because of the very large size of the cells, should improve on the simple OLS estimates. Table 8 shows several estimates of $\frac{1}{\sigma}$ using data for 5 age and 4 education groups over the 1960, 1970, 1980, 1990, 2000 and 2004 years. Columns 1 and 2 present, respectively, the least 
squares weighted and unweighted estimates of $\frac{1}{\sigma}$ (using employment of a cell as weight) and column 3 and 4 show the 2SLS weighted and unweighted estimates of $\frac{1}{\sigma}$. Moving between rows, on the other hand, we have specification 1 that includes all years, specification 2 excluding year 1960, as migration flows were very scant in the 60 's, and specification 3 excluding year 2004, not a census year. Finally specification 4 includes only observations relative to the groups of workers with an high school degree or less. The estimates range between 0.1 and 0.33 with a median of 0.30 , implying $\sigma$ between 3 and 10 , with a median value of 3.33 . This range of estimates includes the estimates obtained at the national level by Ottaviano and Peri (2006) which were mostly between 5 and 10. Most of the values of $\sigma$ for California, however, cluster between 3 and 4 implying an even smaller substitutability between U.S. and foreign-born than estimated at the national level. The only noticeable differences, in the direction of finding smaller coefficients, appear in the specification that omits the year 2004. Recall, however that when omitting one year of data we are using 100 observations to estimate 65 fixed effects and one coefficient, hence we are subject to some imprecision. Certainly, however, these results confirm the findings at the national level; all the estimates of $1 / \sigma$ are significantly larger than 0 , implying imperfect substitutability between U.S.- and foreign-born.

\section{Immigration and Wages, California 1990-2004}

Equipped with the estimates of the parameters from the production function and of the elasticity of natives' supply to immigration we can calculate the impact of immigration (1990-2004) on the wages of natives. Consistent with the insignificant estimates of section 4, we evaluate the wage effects of immigrants assuming zero response of native employment. This exercise has two important objectives. First, to evaluate the actual real wage change of each group in response to immigration, we need to combine the estimated parameters in the formulas (5) and (6) that account for within and across skill complementarities. Second, once we know those wage gains and losses we may check if they are logically consistent with the findings of zero mobility. Specifically, for the group of less educated workers that is likely to have the largest loss/smallest gains it would be important to check whether the wage impact of immigrants is compatible with no migratory response in the presence of small migration costs.

Assuming no significant employment response of native population through migration or change in employment rates, i.e. for $\gamma=0$, the formulas to evaluate wage changes, expressed in (8) and (7) reduce to expressions (5) and (6). Let us remind the reader that those formulas capture the change in wages once physical capital has adjusted to equate its return in California with the returns it earns in the rest of the country. Assuming perfect mobility of capital within the U.S. this adjustment should not take a long time. Table 9 shows the calculated percentage changes of real wages for U.S.- and foreign-born workers by education group and overall for the period 1990-2004. The percentage change for each education group is calculated by averaging the wage 
change in the age-education sub-groups using wage shares in 1990 as weights. Similarly, the percentage changes of real wages of U.S.- and foreign-born workers are obtained by averaging the changes for each education group among U.S.- or foreign-born, weighting each change by the wage share of that education group among U.S.- or foreign-born in 1990. The first column of Table 9 reports the increase in foreign-born workers for each education group as a percentage of the total (U.S. and foreign-born) employment in that group as of 1990. As already shown in Figure 2, the group of high school dropouts received the largest immigration as a percentage of its initial employment (almost 30\%) followed by college graduates, high school graduates and college dropouts. The second column (specification 1) reports the calculated real wage changes due to immigration using the median estimate of $\sigma$ from section $5, \sigma=3.3$. The other parameters' values are kept fixed in all calculations and are equal to the values usually adopted in the literature, namely: $\alpha=0.66$ is based on the estimates of the share of labor income in total GDP for the U.S., $\delta=2$, is based on existing estimates of substitutability of labor across education groups and $\eta=4$ is based on existing estimates of substitutability of labor across experience groups. As we move to the right (specifications 2, 3 and 4) we repeat those calculations using higher estimates of $\sigma$, corresponding to the range of values (between 5 and 10) estimated in section 5 on California data and consistent with the national estimates in Ottaviano and Peri (2006). All effects are long-run effects, i.e. accounting for the full adjustment of physical capital. First of all let us notice that using the estimate $\sigma=3.3$, the imperfect substitutability between foreign-born and natives is strong enough to imply that immigration has a positive effect on each single education group of native workers. On average, natives gain $5 \%$ in productivity as foreign-born provide skills and labor types which complement, rather than substitute for, their own. Even the least educated native workers gain $1.8 \%$ of their real wages and college dropouts gain $7.2 \%$. These are remarkable gains. While in relative terms the group of native high school dropouts is still harmed by immigration, given wage boosts to higher educated workers of 4 to $7 \%$, the high complementarity between natives and immigrants and the large inflow of immigrants increased wages in real terms for all native groups. The motivation and interpretation for these results is that immigrants, among less educated workers, have filled those occupations, jobs and production tasks that use heavily manual skills (e.g. repairing, cultivating, cleaning, packing), leaving native workers to more interactive, language and communication-oriented jobs (e.g. selling, training, organizing, coordinating). The availability of manual workers has made the productivity and demand for the tasks supplied by natives higher. Correspondingly, the increasing supply of immigrants has partly crowded out previous immigrants who occupied similar jobs and occupations, implying an average loss in their productivity as large as $29 \%$. The value of $\sigma=5$ is consistent with the national, as well as the California estimates, and may be the most plausible of all. Column 3 (specification 2) shows the estimated effects given this parameter value. One still obtains positive effects for wages of native workers of any schooling level. High school dropouts experience almost no wage change $(+0.2 \%)$, college graduates and high school graduates experience an increase in real wages by around 
$3 \%$ and college dropouts by $6.7 \%$. Native real wages are boosted by $4.1 \%$, on average, by immigration. Let me emphasize, at this point, that the calculated wage effects are perfectly compatible with the estimated migratory response of natives. Less educated workers have no incentive to move out of the state. More educated workers might have an incentive to move in, however gains on the order of $3 \%$ of their wages may not be enough in the presence of moving costs to attract them. Only the group with some college education (but no degree) has more substantial gains. The small positive migratory response of native population found in section 4 may be a sign of a moderate pull of natives due to productive complementarities. Even allowing for the highest degree of substitutability between U.S. and foreign-born compatible with our estimates, namely $\sigma=10$ reported in specification 4 , immigrants turn out to benefit natives by $2.2 \%$ on average, with a distribution of this effect ranging from a positive wage effects equal to $5.7 \%$ for college dropouts to a negative effect equal to $3 \%$ for high school dropouts. In this case there would be some incentive for the least educated to move to avoid real losses, however moderate costs of moving in the form of actual costs, search costs and on the job skill losses, may easily erode the $3 \%$ gains of a move. All in all, we find it very plausible that, as found in section 4 , these very modest wage changes did not trigger any major out- (in-) migration from (to) California. On the other hand, the negative wage effects of new immigrants on other foreign-born (between -10 and -20\%) may imply that some old immigrants moved out of California as a consequence of new immigration, contributing to the diffusion of immigrants (especially Latinos) across other U.S. states, a phenomenon that typically took place during the nineties (see for instance Card and Lewis, 2005). Recall, however, that part of the large negative effect on foreign-born wages is due to the nature of the experiment, in which we keep all variables constant as of 1990 except for immigration. The increased employment of natives between 1990 and 2004, and their complementarity to foreign-born, certainly acted to reduce the negative effect on old immigrants.

\section{Conclusions}

If U.S. States were independent countries, California would be the second largest receiving country for international migrants in the whole world (after Russia) with its 8.5 million foreign-born as of 2004. Moreover, its proximity to Mexico and a porous border generated extremely large flows of uneducated Mexican workers (documented and undocumented), at a growing rate, during the last three decades. With one third of its total labor force made up by immigrants, two thirds of its uneducated workers coming from abroad and a rapidly rising foreign-born population, that grew by $40 \%$ in the last 14 years, surely native Californians (particularly the unskilled ones) must have suffered the most from the negative effects of this "immigration crisis" 8 on their employment opportunities and wages. The present study, that analyzes employment and wage data in Cali-

\footnotetext{
${ }^{8}$ The expression is paraphrased from an interview with Lou Dobbs of CNN, aired on National Public Radio on May, 1st 2006, entitled "Lou Dobbs and the American Immigration Crisis".
} 
fornia over the 1960-2004 period, seems to say otherwise. On one hand, immigrants do not seem to increase the tendency of natives with similar skills (education and experience) to migrate, or to otherwise change their likelihood of losing their jobs and dropping out of employment. On the other hand, the impact of immigration over the 1990-2004 period has been negative on the wages of previous immigrants and positive on the wages of U.S. natives, revealing a good degree of complementarity between U.S. and foreign-born workers that benefits (rather then harms) native workers' productivity. One plausible interpretation of these complementarities is the following. Manual tasks in most sectors of California economy are executed by immigrants; the larger availability of these skills has increased the demand for interactive-communication-coordination tasks needed in production, and this latter set of skills is more likely provided by natives, even those with low education. This mechanism has worked to help, rather than harm, the demand and wages of natives' labor in California. Our median estimates reveal that these complementarities of immigrants spurred wage growth of natives, once physical capital adjusted, by about $4 \%$ over fourteen years. These average wage gains for natives were distributed as small wage changes $(0.2 \%)$ for high school dropouts and significant wage gains of up to $6.7 \%$ for workers with at least a high school degree. 


\section{References}

Angrist, Joshua (1995) "The Economic Returns to Schooling in the West Bank and Gaza Strip," American Economic Review 85 (1995), 1065-1087.

Aydemir, Abdurrahman and George J. Borjas (2006) "Attenuation Bias in Measuring the Impact of Immigration" Manuscript, Harvard University, June 2006.

Aydemir, Abdurrahman and George J. Borjas (2007) "A comparative analysis of the Labor Market Impact of International Migrations: Canada, Mexico and the United States" NBER Working Paper, \#12327.

Borjas, George J. (2003) "The Labor Demand Curve is Downward Sloping: Reexamining the Impact of Immigration on the Labor Market" Quarterly Journal of Economics, CXVIII (4), 1335-1374.

Borjas, George J. (2006) "Native Internal Migration and the Labor Market Impact of Immigration" Journal of Human Resources XLI.(2), 221-258.

Borjas, George J., Freeman, Richard and Katz, Larry (1997) "How Much do Immigration and Trade Affect Labor Market Outcomes?" Brookings Papers on Economic Activity, 1997 (1), 1-90

Card, David (1990) "The Impact of the Mariel Boatlift on the Miami Labor Market" Industrial and Labor Relation Review, XLIII, 245-257.Card, David (2001) "Immigrant Inflows, Native Outflows, and the Local labor Market Impacts of Higher Immigration" Journal of Labor Economics, XIX (2001), 22-64.

Card, David and Lemieux, Thomas (2001) "Can Falling Supply Explain the Rising Returns to College for Younger Men? A Cohort Based Analysis" Quarterly Journal of Economics, Vol. CXVI, pag. 705-746.

Card, David and Ethan Lewis (2005) "The Diffusion of Mexican Immigrants During the 1990s: Explanations and Impacts," NBER Working Paper \#11552, August 2005.

Ciccone, Antonio and Peri, Giovanni (2005) "Long-Run Substitutability between More and Less Educated Workers: Evidence from U.S. States 1950-1990" Review of Economics and Statistics, Vol. 87, Issue 4.

Hamermesh, Daniel (1993), "Labor Demand", Princeton University Press, Princeton New Jersey, 1993.

Katz, Larry and Murphy, Kevin (1992) "Change in Relative Wages 1963-1987: Supply and Demand Factors," Quarterly Journal of Economics 107, 35-78.

Lewis, Ethan (2005) "Immigration, Skill Mix, and the Choice of Technique," Federal Reserve Bank of Philadelphia Working Paper \#05-08, May 2005 
Manacorda, Marco, Alan Manning and Jonathan Wadsworth (2006) "The Impact of Immigration on the Structure of Male Wages: Theory and Evidence from Britain" manuscript, London School of Economics, June 2006.

Ottaviano, Gianmarco I.P. and Peri Giovanni (2006) "Rethinking the Effects of Immigration on Wages" NBER Working Paper, \#12497.

Ruggles, Steven , Matthew Sobek, Trent Alexander, Catherine A. Fitch, Ronald Goeken, Patricia Kelly Hall, Miriam King, and Chad Ronnander (2006). Integrated Public Use Microdata Series: Version 3.0 [Machine-readable database]. Minneapolis, MN: Minnesota Population Center [producer and distributor], 2004. http://www.ipums.org. 
Table 1:

Percentage of Foreign-Born in Employment and Population 1960-2004

\begin{tabular}{|c|c|c|c|c|c|c|}
\hline Years of Schooling: & $\begin{array}{c}1960 \\
\text { Census }\end{array}$ & $\begin{array}{c}1970 \\
\text { Census }\end{array}$ & $\begin{array}{c}1980 \\
\text { Census }\end{array}$ & $\begin{array}{c}1990 \\
\text { Census }\end{array}$ & $\begin{array}{c}2000 \\
\text { Census }\end{array}$ & $\begin{array}{c}2004 \\
\text { American } \\
\text { Community } \\
\text { Survey } \\
\end{array}$ \\
\hline Total Employment, California & $9.4 \%$ & $10.0 \%$ & $16.1 \%$ & $24.6 \%$ & $32.0 \%$ & $33.2 \%$ \\
\hline Total Employment, U.S.A. & $5.9 \%$ & $5.1 \%$ & $6.4 \%$ & $8.9 \%$ & $13.0 \%$ & $14.4 \%$ \\
\hline Total Population, California & $8.6 \%$ & $8.7 \%$ & $15.6 \%$ & $24.6 \%$ & $29.9 \%$ & $29.9 \%$ \\
\hline Total Population, U.S.A. & $5.2 \%$ & $4.3 \%$ & $6.0 \%$ & $8.7 \%$ & $12.5 \%$ & $13.4 \%$ \\
\hline
\end{tabular}

Note: Author's calculation using Census 1960-2000 and ACS 2004 IPUMS data. Employment is calculated as the sum of individuals of ages between 17 and 66, not residing in group quarters, and who worked at least one week during the preceding year. Population is calculated as the sum of all individuals aged 17 to 66 not residing in group quarters.

Table 2:

Percentage of foreign Born Workers by Schooling, California 1960-2004

\begin{tabular}{|c|c|c|c|c|c|c|}
\hline Years of Schooling: & $\begin{array}{c}1960 \\
\text { Census }\end{array}$ & $\begin{array}{c}1970 \\
\text { Census }\end{array}$ & $\begin{array}{c}1980 \\
\text { Census }\end{array}$ & $\begin{array}{c}1990 \\
\text { Census }\end{array}$ & $\begin{array}{c}2000 \\
\text { Census }\end{array}$ & $\begin{array}{c}2004 \\
\text { American } \\
\text { Community } \\
\text { Survey }\end{array}$ \\
\hline 0 to 11 years & $13.0 \%$ & $15.7 \%$ & $33.7 \%$ & $52.2 \%$ & $63.4 \%$ & $66.8 \%$ \\
\hline 12 years (High School Grads) & $6.4 \%$ & $7.4 \%$ & $11.3 \%$ & $19.1 \%$ & $27.6 \%$ & $31.2 \%$ \\
\hline 13 to 15 years & $7.4 \%$ & $7.8 \%$ & $11.0 \%$ & $15.4 \%$ & $20.6 \%$ & $20.7 \%$ \\
\hline 16 years (College Graduates) & $7.7 \%$ & $8.3 \%$ & $13.9 \%$ & $18.7 \%$ & $24.9 \%$ & $27.9 \%$ \\
\hline Master, Professional Degree & n.a. & n.a. & n.a. & $19.9 \%$ & $26.7 \%$ & $28.9 \%$ \\
\hline Doctoral Degree & n.a. & n.a. & n.a. & $28.5 \%$ & $37.2 \%$ & $42.1 \%$ \\
\hline Average California & $9.4 \%$ & $10.0 \%$ & $16.1 \%$ & $24.6 \%$ & $32.0 \%$ & $33.2 \%$ \\
\hline
\end{tabular}

Note: Author's calculation using Census 1960-2000 and ACS 2004 IPUMS data. Workers included are individuals aged 17-66, not residing in group quarters, and who worked at least one week during the preceding year. 
Table 3:

Response of Native Employment to Immigration:

By Education-Age groups, California 1960-2000

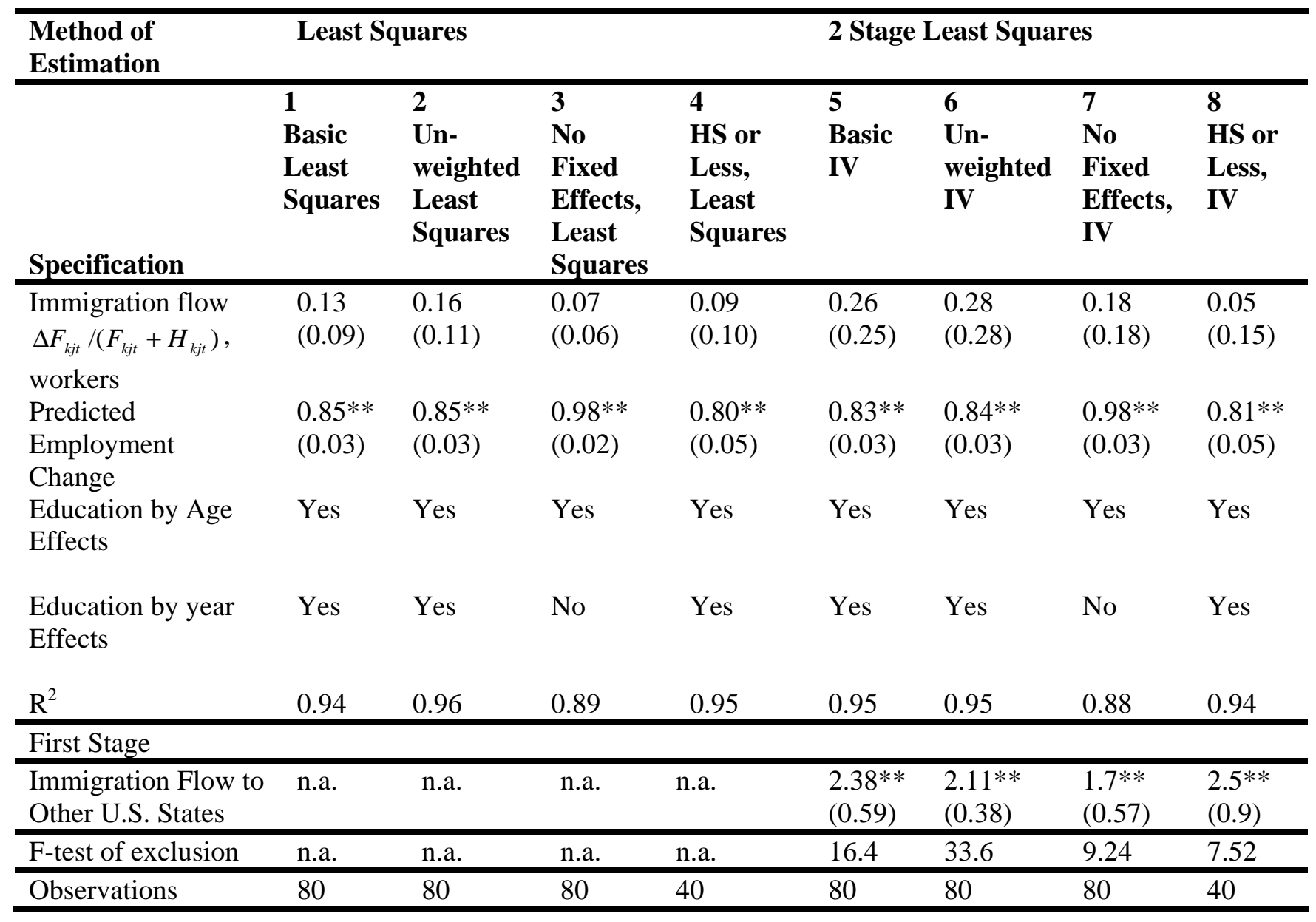

Notes: The dependent variable is the change in employment of U.S.-born workers as a percentage of the initial total employment in the group: $\Delta H_{k j t} /\left(F_{k j t}+H_{k j t}\right)$. Groups are: 4 education by 5 age groups (17 to 66 by ten years of age) over 4 inter-census periods (four decades between 1960 and 2000). Employment is measured as total number of individuals who worked for at least one week in the previous year. Foreign-born are those individuals who were born outside the United States and were not U.S. citizens at birth. Standard errors are clustered by education-age group. Specifications 1 to 4 use OLS as the method of estimation, weighting each observation by the total employment in the cell (except for the unweighted specification 2). Specifications 5 to 8 use 2SLS as the method of estimation adopting immigration by skill group relative to the rest of the U.S. $\Delta F_{k j t}^{U S} /\left(F_{k j t}^{U S}+H_{k j t}^{U S}\right)$ as an instrument for immigration $\Delta F_{k j t} /\left(F_{k j t}+H_{k j t}\right)$ relative to California. The variable "Predicted Employment" is the total employment constructed for each age-education group using the demographics in California (i.e. the size of each cohort measured a decade earlier) and accounting for national rates of mortality and national rates of employment by cohort. 
Table 4:

Response of Native Population to Immigration:

By Education-Age Groups, California 1960-2000

\begin{tabular}{|c|c|c|c|c|c|c|c|c|}
\hline Method of Estimation & Least S & uares & & & 2 Stage & ceast Squa & & \\
\hline Specification & $\begin{array}{l}1 \\
\text { Basic } \\
\text { Least } \\
\text { Squares }\end{array}$ & $\begin{array}{l} \\
\text { Un- } \\
\text { weighted } \\
\text { Least } \\
\text { Squares }\end{array}$ & $\begin{array}{l}3 \\
\text { No } \\
\text { Fixed } \\
\text { Effects, } \\
\text { Least } \\
\text { Squares }\end{array}$ & $\begin{array}{l}4 \\
\text { HS or } \\
\text { Less, } \\
\text { Least } \\
\text { Squares }\end{array}$ & $\begin{array}{l}5 \\
\text { Basic } \\
\text { IV }\end{array}$ & $\begin{array}{l}6 \\
\text { Un- } \\
\text { weighted } \\
\text { IV }\end{array}$ & $\begin{array}{l}7 \\
\text { No Fixed } \\
\text { Effects, } \\
\text { IV }\end{array}$ & $\begin{array}{l}8 \\
\text { HS or } \\
\text { Less, } \\
\text { IV }\end{array}$ \\
\hline $\begin{array}{l}\text { Immigration flow } \\
\Delta F_{k j t} /\left(F_{k j t}+H_{k j t}\right) \text {, } \\
\text { Population }\end{array}$ & $\begin{array}{l}0.13 \\
(0.09)\end{array}$ & $\begin{array}{l}0.14 \\
(0.11)\end{array}$ & $\begin{array}{l}0.01 \\
(0.04)\end{array}$ & $\begin{array}{l}0.08 \\
(0.06)\end{array}$ & $\begin{array}{l}0.29 \\
(0.24)\end{array}$ & $\begin{array}{l}0.27 \\
(0.28)\end{array}$ & $\begin{array}{l}0.15 \\
(0.15)\end{array}$ & $\begin{array}{l}0.05 \\
(0.13)\end{array}$ \\
\hline $\begin{array}{l}\text { Predicted } \\
\text { Population } \\
\text { Change }\end{array}$ & $\begin{array}{l}0.90^{* *} \\
(0.04)\end{array}$ & $\begin{array}{l}0.90^{* *} \\
(0.04)\end{array}$ & $\begin{array}{l}1.02^{* *} \\
(0.03)\end{array}$ & $\begin{array}{l}0.81^{* *} \\
(0.07)\end{array}$ & $\begin{array}{l}0.87^{* *} \\
(0.04)\end{array}$ & $\begin{array}{l}0.88 * * \\
(0.04)\end{array}$ & $\begin{array}{l}1.03 * * \\
(0.04)\end{array}$ & $\begin{array}{l}0.83^{* *} \\
(0.07)\end{array}$ \\
\hline $\begin{array}{l}\text { Education by Age } \\
\text { Effects }\end{array}$ & Yes & Yes & Yes & Yes & Yes & Yes & Yes & Yes \\
\hline $\begin{array}{l}\text { Education by Year } \\
\text { Effects }\end{array}$ & Yes & Yes & No & Yes & Yes & Yes & No & Yes \\
\hline $\mathrm{R}^{2}$ & 0.95 & 0.94 & 0.88 & 0.93 & 0.94 & 0.95 & 0.87 & 0.93 \\
\hline Observations & 80 & 80 & 80 & 40 & 80 & 80 & 80 & 40 \\
\hline
\end{tabular}

Notes: The dependent variable is the change in population of U.S.-born workers as a percentage of the initial total population in the group: $\Delta H_{k j t} /\left(F_{k j t}+H_{k j t}\right)$. Groups are: 4 education by 5 age groups (17 to 66 by ten years of age) over 4 inter-census periods (four decades between 1960 and 2000). Foreign-born are those individuals who were born outside the United States and not U.S. citizen at birth. Standard errors are clustered by education-age group. Specifications 1 to 4 use OLS as method of estimation, weighting each observation by the total employment in the cell (except for the not weighted specification 2). Specifications 5 to 8 use 2SLS as method of estimation adopting immigration by skill group relative to the rest of the US $\Delta F_{k j t}^{U S} /\left(F_{k j t}^{U S}+H_{k j t}^{U S}\right)$ as an instrument for immigration $\Delta F_{k j t} /\left(F_{k j t}+H_{k j t}\right)$ relative to California. The variable "Predicted Population" is the total population constructed for each age-education group using the demographics in California (i.e. the size of each cohort measured a decade earlier) and accounting for national rates of mortality by cohort. 
Table 5:

Response of Native Employment/Population Ratios to Immigration:

By Education-Age groups, California 1960-2000

\begin{tabular}{|c|c|c|c|c|c|c|c|c|}
\hline \multirow[b]{2}{*}{ Specification } & \multicolumn{4}{|c|}{ Least Squares } & \multicolumn{4}{|c|}{2 Stage Least Squares } \\
\hline & $\begin{array}{l}1 \\
\text { Basic } \\
\text { Least } \\
\text { Squares }\end{array}$ & $\begin{array}{l}2 \\
\text { Un- } \\
\text { weighted } \\
\text { Least } \\
\text { Squares }\end{array}$ & $\begin{array}{l}3 \\
\text { No } \\
\text { Fixed } \\
\text { Effects, } \\
\text { Least } \\
\text { Squares }\end{array}$ & $\begin{array}{l}4 \\
\text { HS or } \\
\text { Less, } \\
\text { Least } \\
\text { Squares }\end{array}$ & $\begin{array}{l}5 \\
\text { Basic } \\
\text { IV }\end{array}$ & $\begin{array}{l}6 \\
\text { Un- } \\
\text { weighted } \\
\text { IV }\end{array}$ & $\begin{array}{l}7 \\
\text { No Fixed } \\
\text { Effects, } \\
\text { IV }\end{array}$ & $\begin{array}{l}8 \\
\text { HS or } \\
\text { Less, } \\
\text { IV }\end{array}$ \\
\hline $\begin{array}{l}\text { Immigration flow } \\
\Delta F_{k j t} /\left(F_{k j t}+H_{k j t}\right), \\
\text { population }\end{array}$ & $\begin{array}{l}0.05 \\
(0.05)\end{array}$ & $\begin{array}{l}0.02 \\
(0.05)\end{array}$ & $\begin{array}{l}0.05 \\
(0.03)\end{array}$ & $\begin{array}{l}0.08 \\
(0.06)\end{array}$ & $\begin{array}{l}0.02 \\
(0.05)\end{array}$ & $\begin{array}{l}0.01 \\
(0.05)\end{array}$ & $\begin{array}{l}0.06^{*} \\
(0.03)\end{array}$ & $\begin{array}{l}0.08 \\
(0.05)\end{array}$ \\
\hline $\begin{array}{l}\text { National } \\
\text { Employment/ } \\
\text { Population Ratio } \\
\text { Change }\end{array}$ & $\begin{array}{l}0.88^{* *} \\
(0.06)\end{array}$ & $\begin{array}{l}0.91^{* *} \\
(0.06)\end{array}$ & $\begin{array}{l}0.88^{* *} \\
(0.07)\end{array}$ & $\begin{array}{l}0.91^{* *} \\
(0.10)\end{array}$ & $\begin{array}{l}0.87^{* *} \\
(0.08)\end{array}$ & $\begin{array}{l}0.91^{* *} \\
(0.07)\end{array}$ & $\begin{array}{l}0.89 * * \\
(0.08)\end{array}$ & $\begin{array}{l}0.92 * * \\
(0.10)\end{array}$ \\
\hline $\begin{array}{l}\text { Education by Age } \\
\text { Effects }\end{array}$ & Yes & Yes & Yes & Yes & Yes & Yes & Yes & Yes \\
\hline $\begin{array}{l}\text { Education by Year } \\
\text { Effects }\end{array}$ & Yes & Yes & No & Yes & Yes & Yes & No & Yes \\
\hline $\mathrm{R}^{2}$ & 0.88 & 0.88 & 0.78 & 0.88 & 0.88 & 0.88 & 0.78 & 0.87 \\
\hline Observations & 80 & 80 & 80 & 40 & 80 & 80 & 80 & 40 \\
\hline
\end{tabular}

Notes: The dependent variable is the change of employment/population ratios of U.S.-born workers during each inter-census period. Employment/population ratios are defined as the number of individuals working divided by total population in each age-education group. Groups are: 4 education by 5 age groups (17 to 66 by ten years of age) over 4 inter-census periods (four decades between 1960 and 2000). Foreign-born are those individuals who were born outside the United States and not U.S. citizen at birth. Standard errors are clustered by education-age group. Specifications 1 to 4 use OLS as the method of estimation, weighting each observation by the total employment in the cell (except for the not weighted specification 2). Specifications 5 to 8 use 2SLS as the method of estimation adopting immigration by skill group relative to the rest of the U.S. $\Delta F_{k j t}^{U S} /\left(F_{k j t}^{U S}+H_{k j t}^{U S}\right)$ as an instrument for immigration $\Delta F_{k j t} /\left(F_{k j t}+H_{k j t}\right)$ relative to California. The variable "National Employment/Population Ratio" is relative to the group in the U.S, it captures the employment tendencies at the national level. 
Table 6:

Response of Native Employment to Immigration:

By Education Groups, California 1960-2000

\begin{tabular}{|c|c|c|c|c|}
\hline \multirow{2}{*}{$\begin{array}{l}\text { Method of Estimation } \\
\text { Specification }\end{array}$} & \multicolumn{2}{|c|}{ Least Squares } & \multicolumn{2}{|c|}{2 Stage Least Squares } \\
\hline & $\begin{array}{l}1 \\
\text { Employment }\end{array}$ & $\begin{array}{l}2 \\
\text { Employment } \\
\text { Rate } \\
\end{array}$ & $\begin{array}{l}3 \\
\text { Employment }\end{array}$ & $\begin{array}{l}4 \\
\text { Employment } \\
\text { Rate }\end{array}$ \\
\hline $\begin{array}{l}\text { Immigration flow } \\
\Delta F_{k t} /\left(F_{k t}+H_{k t}\right) \text {, population }\end{array}$ & $\begin{array}{l}0.17 \\
(0.19)\end{array}$ & $\begin{array}{l}0.15 \\
(0.19)\end{array}$ & $\begin{array}{l}0.08 \\
(0.24)\end{array}$ & $\begin{array}{l}0.15 \\
(0.22)\end{array}$ \\
\hline $\begin{array}{l}\text { Predicted Employment } \\
\text { (Employment Rate) } \\
\text { Change }\end{array}$ & $\begin{array}{l}0.86^{* *} \\
(0.19)\end{array}$ & $\begin{array}{l}0.77 * * \\
(0.28)\end{array}$ & $\begin{array}{l}1.22 * * \\
(0.19)\end{array}$ & $\begin{array}{l}1.23^{* *} \\
(0.34)\end{array}$ \\
\hline Age-Specific Time Trend & Yes & Yes & Yes & Yes \\
\hline Age-Specific Fixed Effect & Yes & Yes & Yes & Yes \\
\hline $\mathrm{R}^{2}$ & 0.97 & 0.88 & 0.98 & 0.99 \\
\hline Observations & 16 & 16 & 16 & 16 \\
\hline
\end{tabular}

Note: The dependent variable is the change in employment of U.S.-born workers as percentage of the initial total employment in the education group: $\Delta H_{k t} /\left(F_{k t}+H_{k t}\right)$. Groups are: 4 education groups (high school dropouts, high school graduates, college dropouts and college graduates) over 4 inter-census periods (four decades between 1960 and 2000). We only include individuals 27 to 66 years old who are likely to have completed their studies. Standard errors are clustered by education group. The variable "Predicted Employment" is the total employment constructed for each education group using the demographics in California (i.e. the size of each cohort measured a decade earlier), accounting for national rates of mortality and national rates of employment. The IV strategy used in specification 3 and 4 uses migration to the rest of the U.S. by age group as an instrument for California immigration. 
Table 7:

Response of Native Employment to Immigration:

By Age Groups, California 1960-2000

\begin{tabular}{|c|c|c|c|c|}
\hline Method of Estimation & Least Squar & & 2 Stage Least & lares \\
\hline Dependent Variable: & $\begin{array}{l}1 \\
\text { Employment }\end{array}$ & $\begin{array}{l}2 \\
\text { Employment } \\
\text { Rate }\end{array}$ & $\begin{array}{l}3 \\
\text { Employment }\end{array}$ & $\begin{array}{l}4 \\
\text { Employment } \\
\text { Rate }\end{array}$ \\
\hline $\begin{array}{l}\text { Immigration flow } \\
\Delta F_{j t} /\left(F_{j t}+H_{j t}\right) \text {, population }\end{array}$ & $\begin{array}{l}0.08 \\
(0.77)\end{array}$ & $\begin{array}{l}0.14 \\
(0.14)\end{array}$ & $\begin{array}{l}0.70 \\
(0.80)\end{array}$ & $\begin{array}{l}0.18 \\
(0.20)\end{array}$ \\
\hline $\begin{array}{l}\text { Predicted Employment } \\
\text { (Employment Rate) } \\
\text { Change }\end{array}$ & $\begin{array}{l}0.82^{* *} \\
(0.16)\end{array}$ & $\begin{array}{l}0.85^{* *} \\
(0.14)\end{array}$ & $\begin{array}{l}0.91^{* *} \\
(0.15)\end{array}$ & $\begin{array}{l}0.76^{* *} \\
(0.14)\end{array}$ \\
\hline Age-Specific Time Trend & Yes & Yes & Yes & Yes \\
\hline Age-Specific Fixed Effect & Yes & Yes & Yes & Yes \\
\hline $\mathrm{R}^{2}$ & 0.84 & 0.82 & 0.90 & 0.45 \\
\hline Observations & 20 & 20 & 20 & 20 \\
\hline
\end{tabular}

Note: The dependent variable in specifications 1 and 3 is the change in employment of U.S.-born workers as a percentage of the initial total employment in the age group: $\Delta H_{j t} /\left(F_{j t}+H_{j t}\right)$. The dependent variable in specifications 2 and 4 is the change in employment rate. Groups are: 5 age groups (17 to 66 by ten years of age) over 4 inter-census periods (four decades between 1960 and 2000). Standard errors are clustered by age group. The variable "Predicted Employment" is the total employment constructed for each age group using the demographics in California (i.e. the size of each cohort measured a decade earlier), accounting for national rates of mortality and national rates of employment. The IV strategy used in specifications 3 and 4 uses migration to the rest of the U.S. by age group as an instrument for California immigration. 
Table 8:

Estimates of Relative Wage Elasticity of U.S.- and Foreign-born workers (1/ $\sigma)$, California, 1960-2004

\begin{tabular}{lllll}
\hline Estimates of $\mathbf{1} / \boldsymbol{\sigma}$ & \multicolumn{2}{c}{ Ordinary Least Squares } & \multicolumn{2}{c}{ 2 Stage Least Squares } \\
\hline & Weighted & Unweighted & Weighted & Unweighted \\
\hline 1: Basic & $0.33^{* *}$ & $0.28^{* *}$ & $0.33^{* *}$ & $0.24^{* *}$ \\
& $(0.10)$ & $(0.10)$ & $(0.12)$ & $(0.12)$ \\
2: Omitting Year 1960 & $0.33^{* *}$ & $0.31^{* *}$ & $0.33^{* *}$ & $0.31^{* *}$ \\
& $(0.09)$ & $(0.09)$ & $(0.11)$ & $(0.11)$ \\
3: Omitting Year 2004 & $0.14^{* *}$ & $0.13^{* *}$ & $0.10^{* *}$ & $0.10^{* *}$ \\
& $(0.04)$ & $(0.03)$ & $(0.04)$ & $(0.04)$ \\
4: High School or Less & $0.28^{* *}$ & $0.26^{* *}$ & $0.38^{* *}$ & $0.36^{* *}$ \\
& $(0.07)$ & $(0.08)$ & $(0.08)$ & $(0.09)$ \\
\hline
\end{tabular}

Note: Each cell corresponds to the estimate of the coefficient $1 / \sigma$ from a separate regression of (9) in the main text. The dependent variable in each regression is the relative log weekly wage between U.S.-born and foreign-born workers in the group. The explanatory variable is the relative employment of U.S.- and foreign-born workers in the group. The regressions control for age by education, age by year and education by year fixed effects. Groups are: 5 age groups by 4 education groups over 5 census years (1960-2000) plus 2004. The total number of observations for row 1 is 120, for rows 2 and 3 is 100 and for row 4 is 60 . The method of estimation for the first and second column is least squares. For the third and fourth column we use two stage least squares using the supply of immigrants relative to natives in the rest of the country as an instrument for their supply in California. The instrument has an F-test equal to 92 in the first stage of the IV regression. In the specifications of column 1 and 3 we weight each cell by total employment. 
Table 9:

Calculated Percentage Changes in Real Wages of California due to Immigrant Inflows: Effects with Full Physical Capital Adjustment, 1990-2004.

\begin{tabular}{|c|c|c|c|c|c|}
\hline Estimates of $\sigma$ & $\begin{array}{c}\text { Immigration as a } \\
\text { Percentage of } 1990 \\
\text { Group } \\
\text { Employment }\end{array}$ & $\begin{array}{c}1 \\
\text { Median estimate } \\
\text { for California } \\
\sigma=3.3\end{array}$ & $\begin{array}{c}2 \\
\text { Low National } \\
\text { estimate } \\
\sigma=5\end{array}$ & $\begin{array}{c}3 \\
\begin{array}{c}\text { Median National } \\
\text { estimate } \\
\sigma=6.6\end{array}\end{array}$ & $\begin{array}{l}4 \\
\text { Upper bound } \\
\text { National and } \\
\text { California } \\
\sigma=10\end{array}$ \\
\hline & & \multicolumn{4}{|c|}{ \% Real Wage Change of US-Born Workers due to immigration } \\
\hline $\begin{array}{l}\text { HS dropouts U.S.-born } \\
\text { HS graduates, U.S.-born } \\
\text { CO dropouts, U.S.-born } \\
\text { CO graduates, U.S.-born }\end{array}$ & $\begin{array}{l}-- \\
-- \\
-- \\
--\end{array}$ & $\begin{array}{l}+1.8 \% \\
+3.9 \% \\
+7.2 \% \\
+4.0 \%\end{array}$ & $\begin{array}{l}+0.2 \% \\
+2.9 \% \\
+6.7 \% \\
+3.0 \%\end{array}$ & $\begin{array}{l}-1.3 \% \\
+1.8 \% \\
+6.2 \% \\
+1.9 \%\end{array}$ & $\begin{array}{l}-3.0 \% \\
+0.6 \% \\
+5.7 \% \\
+0.7 \%\end{array}$ \\
\hline \multirow[t]{2}{*}{ Average, U.S.-born } & -- & $+5.0 \%$ & $+4.1 \%$ & +3.2 & $+2.2 \%$ \\
\hline & & \multicolumn{4}{|c|}{ \% Real Wage Change of Foreign- Born Workers due to immigration } \\
\hline $\begin{array}{l}\text { HS dropouts Foreign-born } \\
\text { HS graduates, Foreign-born } \\
\text { CO dropouts, Foreign-born } \\
\text { CO graduates, Foreign-born } \\
\text { Average Foreign-born }\end{array}$ & $\begin{array}{l}29.8 \% \\
24.9 \% \\
10.1 \% \\
26.0 \% \\
\mathbf{2 0 . 1 \%} \\
\end{array}$ & $\begin{array}{l}-13.1 \% \\
-31.1 \% \\
-10.7 \% \\
-29.4 \% \\
-20.3 \%\end{array}$ & $\begin{array}{l}-12.1 \% \\
-25.2 \% \\
-7.1 \% \\
-24.2 \% \\
-\mathbf{1 6 . 8 \%}\end{array}$ & $\begin{array}{c}-10.5 \% \\
-19.5 \% \\
-4.6 \% \\
-18.1 \% \\
-\mathbf{1 3 . 1 \%}\end{array}$ & $\begin{array}{c}-8.9 \% \\
-13.4 \% \\
-1.1 \% \\
-12.3 \% \\
\mathbf{- 9 . 1 \%}\end{array}$ \\
\hline $\begin{array}{l}\text { Overall Average: } \\
\text { U.S.- and Foreign-Born }\end{array}$ & -- & 0\% & $\mathbf{0 \%}$ & $\mathbf{0 \%}$ & $\mathbf{0 \%}$ \\
\hline
\end{tabular}

Note: Values of the other parameters used in the calculations: $\delta=2, \eta=4, \alpha=0.66$. The percentage change for the wage of each worker in group $k$, $j$ is calculated using formula (5) for U.S.-born and (6) for foreign-born from the main text. Then percentage wage changes are averaged across age groups using the wage-share of the group in 1990 to obtain the table entries. The averages for U.S.- and Foreign-born are obtained by averaging the wage change of each education group weighted by its share in wage in 1990. The overall average wage change adds the change of U.S.- and foreign-born weighted for the relative wage shares in 1990. As physical capital adjusts to maintain the capital labor ratio fixed, the effects on overall average wage (in the last row) are always 0. 
Figure 1:

Percentage of Foreign-Born Workers by Education Group, 2004

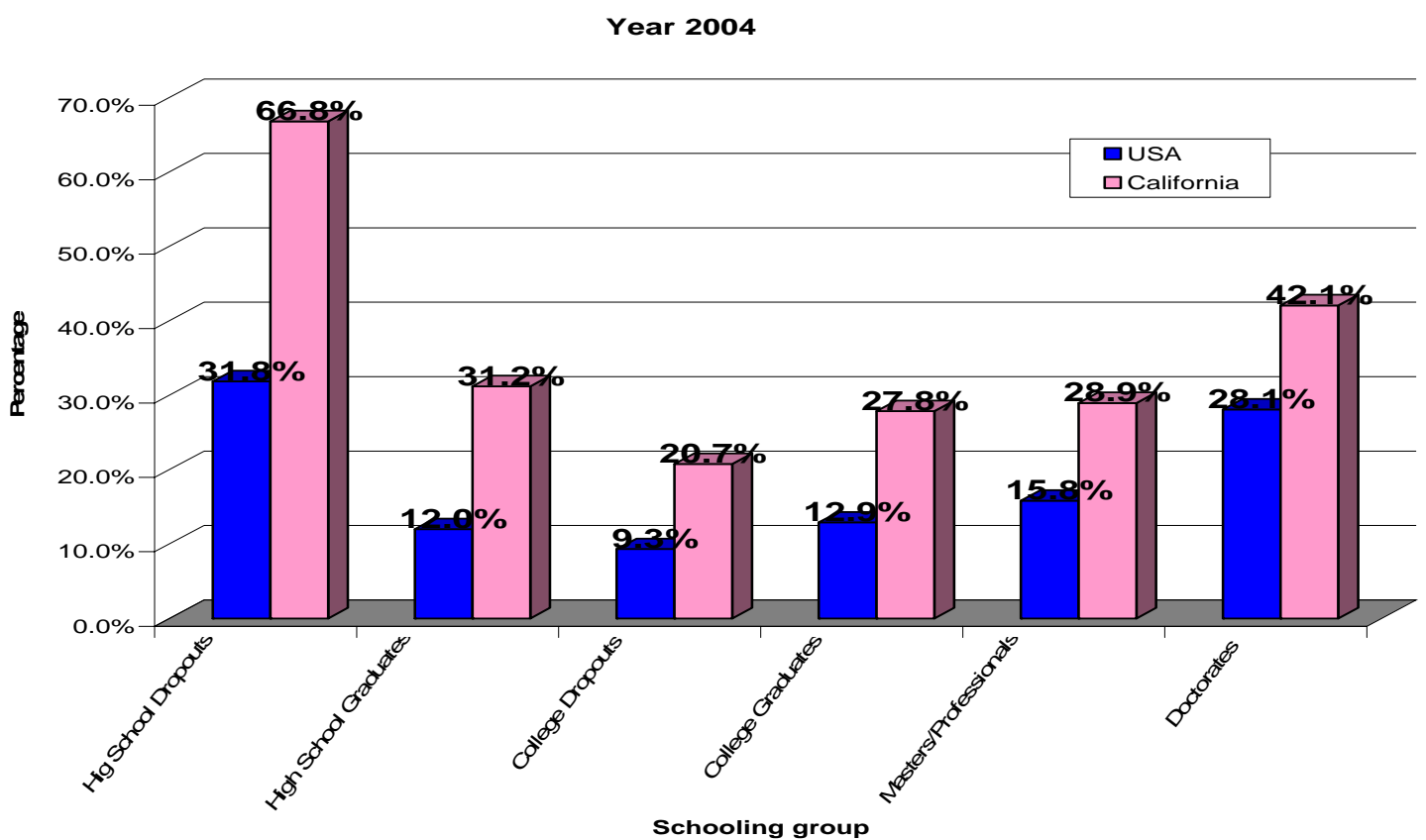

Figure 2:

Immigration Flows by Education Group, 1990-2004

Immigrants 1990-2004 as percentage of Employment in 1990

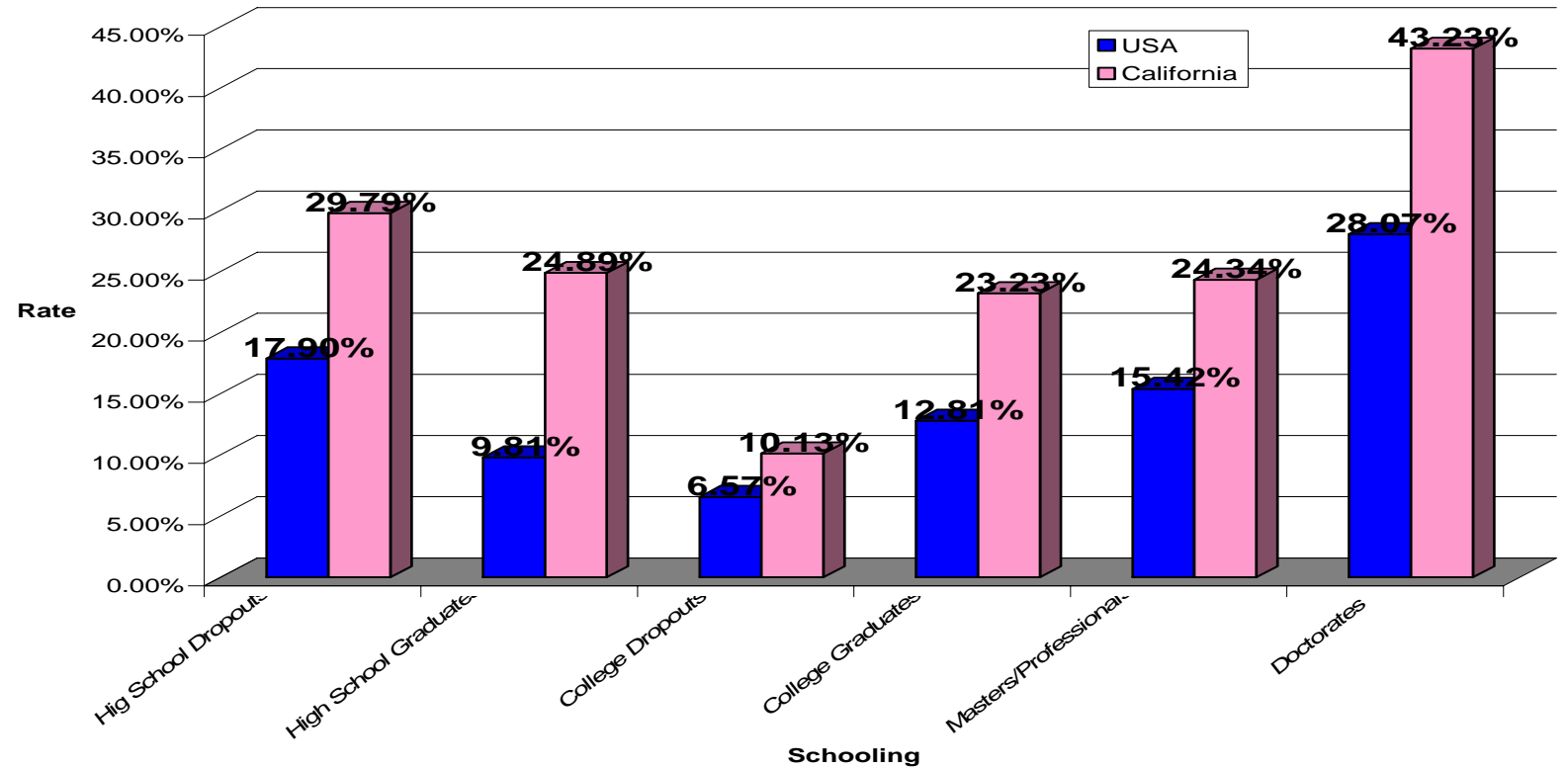


Figure 3:

Change in the Real Wage of U.S. Natives, by Education Group, 1990-2004.

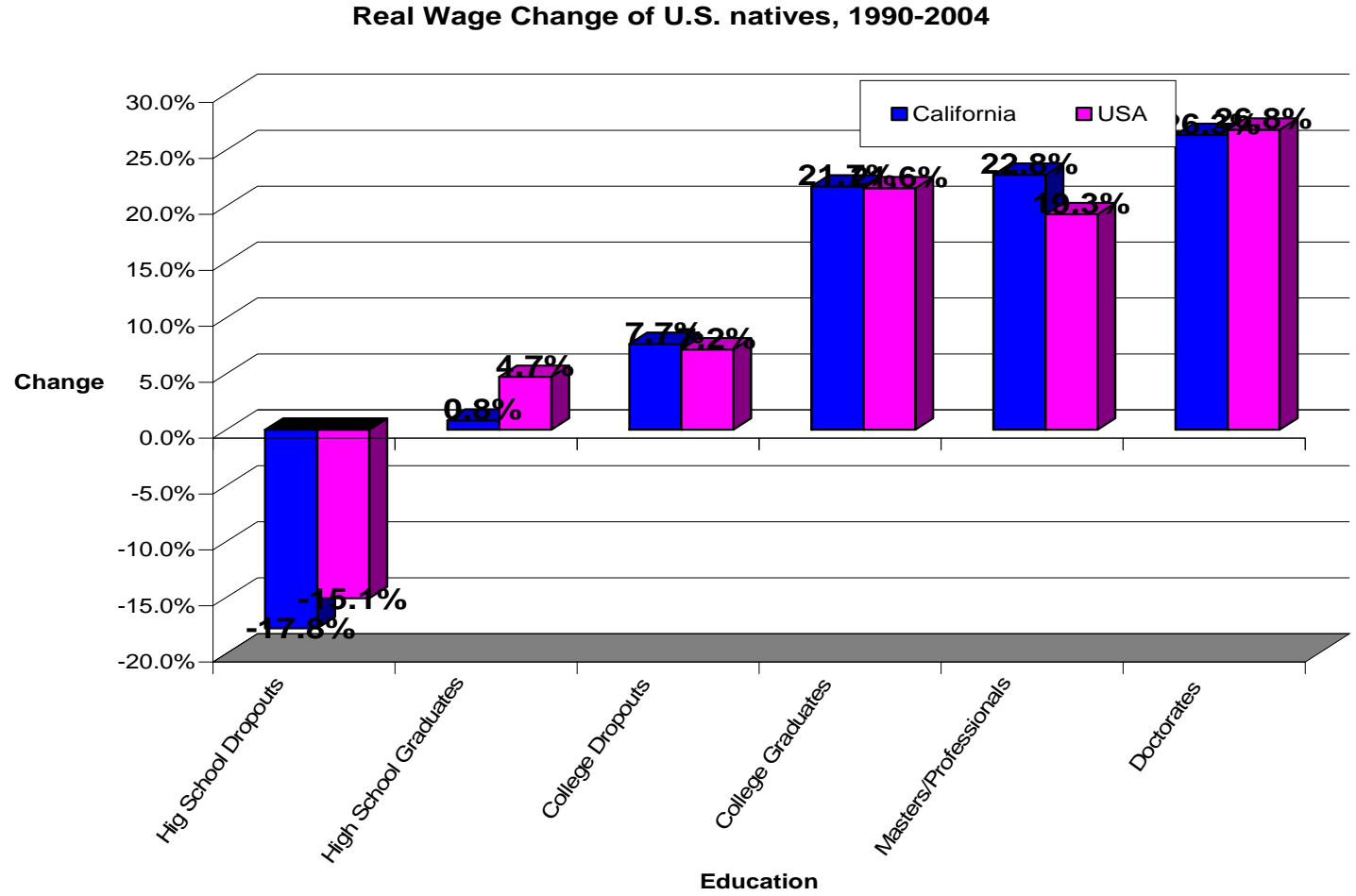

